\title{
Neuroscience-based Physical Education Learning Environment: An Analysis
}

\author{
Yusmawati*, Eva Julianti, Ruliando Hasea Purba \\ Faculty of Sport Science, Universitas Negeri Jakarta, Jakarta, 13220, Jakarta Timur, Indonesia
}

Received September 22, 2020; Revised November 30, 2020; Accepted December 22, 2020

\section{Cite This Paper in the following Citation Styles}

(a): [1] Yusmawati, Eva Julianti, Ruliando Hasea Purba, "Neuroscience-based Physical Education Learning Environment: An Analysis," International Journal of Human Movement and Sports Sciences, Vol. 8, No. 6A, pp. 36-41, 2020. DOI: $10.13189 /$ saj.2020.080706.

(b): Yusmawati, Eva Julianti, Ruliando Hasea Purba (2020). Neuroscience-based Physical Education Learning Environment: An Analysis. International Journal of Human Movement and Sports Sciences, 8(6A), 36-41. DOI: 10.13189/saj.2020.080706.

Copyright $\bigcirc 2020$ by authors, all rights reserved. Authors agree that this article remains permanently open access under the terms of the Creative Commons Attribution License 4.0 International License

\begin{abstract}
This research is part of the research and development phase conducted by researchers. The purpose of this study is to describe the physical education learning environment by integrating the neuroscience concept. The method used in this research is literature study and survey with the following steps, 1) conducting a theoretical study and related principles, 2) analyzing learning (including analysis of learning tools to its implementation), and 3) describing the findings. The subjects in this study were grade 3 elementary school physical education teachers in Jakarta. The instrument used was developed by the researcher according to the needs consisting of four indicators, namely, the teacher's teaching style, student learning styles, the integration of neuroscience in learning, and learning support facilities. Literature study data were analyzed using a normative approach while survey data were analyzed using descriptive analysis. The results obtained are that there are four main principles of neuroscience learning, namely 1) multi-tasking, 2) modeling, 3) fun, 4) sequential. Meanwhile, field findings show that teachers have unconsciously integrated neuroscience in learning, but have never seriously and specifically designed their learning according to the principles of neuroscience-based learning. Researchers suggest developing a neuroscience-based physical education learning model that is based on the found neuroscience learning principles.
\end{abstract}

Keywords Neuroscience, Learning Environment, Physical Education

\section{Introduction}

The learning process is an important activity in the education system. Learning determines the success of achieving the goals or competencies expected by teachers, schools, and even the state, because education is one of the extraordinary tools that can be used by the state to improve the quality of its people.

Every learning process that is carried out must involve the performance of the brain. The purpose of brain performance is thought. Every healthy human brain, regardless of one's age, gender, nationality, or cultural background, is equipped with an extraordinary set of features: 1) the ability to detect patterns and make predictions, 2) phenomenal capacity for different types of memory, 3) ability to self-correct and learn from experience by analyzing external data and self-reflection, and 4) an inexhaustible capacity to create [1]. Even though the science of the brain has a lot of scope, many researchers have mapped the scope of people's performance in relation to the educational process. The direction of the learning approach, which is currently developing into student-centered learning, is one form of contribution to finding research on the brain related to learning. Students have the capacity to carry out learning independently with facilitation from various learning sources, especially by teachers. This shows that the human 
mind has an important role in the learning process, not only at the level of memorization, understanding and even creation, but also in psychological aspects (motivation, emotions, meaning) and also socio-culture. Students are empowered to take responsibility for their own learning, with teachers and other professionals as facilitators [2].

The involvement of the mind in learning can help students understand the various information they receive so that it becomes more meaningful, especially for elementary school students. One is deliberately designed to actively engage young children's minds to help strengthen their neurological networks [3]. Neurons are single cells, with a cell body, or soma, which houses DNA and proteins that guide their function. Each neuron has one axon that sends messages and thousands of dendrites that receive messages. Dendrites appear like tree branches, with more branches representing more connections. This connection represents learning [4].

The strengthening of neurological networks that is expected to occur during the learning process will further improve the performance of nerves more thoroughly. This is because the central nervous system is experiencing good development. Considering how this nervous system changes during learning and development may prove beneficial for efforts to adapt educational approaches to the unique needs of children arriving at the doorsteps of formal education, making a significant difference in highly neural systems where educational practice must be established [5].

By being actively involved in learning, the teacher expects a growth process for the student's neurological network. The growing and developing the neurological network of students' thinking capacities. however, the stimulus provided by the teacher, does not necessarily have a positive impact. On the other hand, the stimulus that is given, if it exceeds the intensity that is in accordance with the characteristics of students, it will actually cause setbacks, in this case it can trigger stress and become unmotivated to learn. Inappropriate or excessive levels of stimulus can reach levels that cause stress and anxiety, caused by tasks that are beyond the individual's skills, abilities and / or comfort [4].

Brain Based Education is engagement strategy with goals that apply to the way our brains work in an educational context. Brain-based learning is called a combination of brain science and common sense. "Brain-based" learning activities engage both hemispheres of the brain simultaneously, resulting in stronger and more meaningful learning experiences and permanent brain connections [6].

Most of the stimulus is given by giving quizzes, assignments or even creating a project. It is not uncommon for this method to require students to study outside the classroom excessively which can take up time to play and rest that should be done during school hours. Of course, the form of assignments and projects is not wrong, but the level of difficulty and assignments from other subjects need to be considered in order to provide a more appropriate dose of stimulus. With all this information, a teacher must be able to design an active, positive, fun and meaningful learning environment with an appropriate stress level. Through the guidance of neuro education, teacher awareness will be achieved to create a context that creates an emotional environment that facilitates effective and effective learning [7].

It is not certain whether the brain shapes the environment, or the environment that shapes the brain's performance. However, these two things are very closely related and especially in learning, it really depends on the age of one's development. For children who are at the elementary school level, the environment may have a bigger role in shaping their behavior, while for adults who already have various experiences, it may be possible to create their own environment based on their creativity. Thus, the learning environment for children in primary schools must be seriously designed in order to be able to achieve more precise and effective learning goals.

The learning environment designed by the teacher must be very diverse, according to the characteristics of the subject and material presented. One of the subjects that havea unique approach is the physical education subject. This subject carries out learning through various physical activities. Physical education is not only designed to create a learning environment to improve movement literacy, but also to improve cognitive, affective, and physical aspects.

Improved brain performance, not only can be developed through theoretical learning. But it can also be developed through various experiences of physical activity. A body of research has emerged showing that physical activity has a beneficial effect on brain structure and function. During the same period, concern has been increasing over high rates of childhood obesity. Considering that schools have been asked to increase academic achievement and childhood obesity rates, it is surprising that schools have not exploited research on the cognitive effects of physical activity [8]. In Indonesia, Physical education classess for final grade pupils at each level of education refers to learning activities for subjects that will be tested during the national exam. This certainly has an impact on the reduced physical activity of students and increases the children's thinking time and of course the children's sitting time while studying or listening. This then actually creates the potential for children who are sedentary which can systemically affect brain performance. On the other hand, disrupting academic teaching time to provide physical activity through physical education does not have a positive effect on achievement but is also not harmful [9].

Physical education learning for elementary schools must be designed to make students actively involved in learning. This aims to create learning that students enjoy. Things that are liked by children tend to be better 
remembered until they are repeated by students. To be able to create an active learning environment must at least fulfill the important components in learning. An active learning environment requires many components that work independently of each other and also regulate overall conditions. As an example:

a). The physical arrangement of tables, chairs, centers, libraries, lighting and other components attracts the child's interest;

b). Spaces designed for individual work, small groups and large group meetings;

c). Availability of manipulative materials and space for exploration that arouses children's natural curiosity; large blocks of time for children to explore, role play, and experiment; and

d). Perhaps most importantly, a loving and caring educator who demonstrates a love for learning and modeling positive interactions.

Make efforts to create a learning environment in such a way that teachers need to do so that the maximum potential of students can be optimized. Physical education has a central role in developing all aspects of students' self when it is designed appropriately, especially in involving cognitive activities. Therefore, this study aims to analyze the learning environment of primary school physical education which is integrated with the basic concepts of neuroscience.

\section{Material Methods}

This research is part of the research and development phase conducted by researchers. The first method is used literature study to synthesize existing neuroscience-based learning theories and principles. The second is a survey to collect information on neuroscience-based physical education learning in elementary schools.

The subjects of this study were elementary school physical education teachers in DKI Jakarta.

The object of library research is in the form of literature works in the form of scientific journals, books, articles in mass media (either in print or in electronic form).

The instrument used for the survey was a questionnaire developed by researchers consisting of four neuroscience-based learning indicators 1) multi-tasking, 2) modeling, 3) fun, 4) sequences, which were modified based on the Creating a learning environment for all children. Source: Smith et al. (1995) with the Neuroscience Model Concept for learning developed by Lila Davachi, Associate Professor of Psychology at New York University.

Literature study data were analyzed using a normative approach, while survey data were analyzed using descriptive analysis.

Through the results of this study, we hope to get a theoretical and empirical basis in developing a neuroscience-based physical education learning model. With some neuroscience-based learning findings, we tried to compile a neuroscience-based physical education algorithm. In addition, we hope that the data obtained from observations can be the basis for developing an appropriate neuroscience-based physical education learning curriculum.

\section{Result and Discussion}

In the first stage, the researcher conducted a literature review regarding the neuroscience-based learning. Physical activity through physical education does not directly affect academic achievement, but it is also not dangerous if it is done. it will provide more support for the brain's physiological performance [10][9][11].

Although it does not have a direct contribution to academic achievement, physical education through physical activity can be a support to optimize other potentials of children, for example cognitive, affective, and social. In the hierarchy of levels of explanation, the sciences of human movement play an important, but nonetheless a supporting or sub ordinate role, concerned with the investigation of the mechanisms, instruments or means which are relevant to the achievement of the normative or intentional ends with which we are essentially occupied [12]. One of the physical education learning methods that can improve theoretical understanding is the physical education learning model through discussion, discussion teaching method is very effective in the teaching and learning of PHE in theory, therefore, the subject should be structured towards active and participatory learning [13].

However, researchers believe that the right physical activity and in accordance with the dosage will actually contribute positively to physiological performance in general, especially brain performance. There is a significant positive relationship between physical activity and cognitive functioning in children [14]. One form of the development of this understanding is the concept of Brain breaks for elementary school children [15][16]. Children are given some time to do physical activity in between lessons to relax the left hemisphere and increase the supply of oxygen to the brain.

Through physical education learning, students are not only physically active, but also involve elements of themselves more complexly. Even through physical education it can stimulate social and ethical personal development, and address the holistic education of children in physical, cognitive, emotional and social aspects. Physical Education also relates directly to the perspective of neuroscience, through recreational activities and daily movement actions based on the basic concepts necessary for life [17].

Learning carried out by the teacher should be able to 
support brain development. In this way, the teacher can better understand the child's learning needs according to the expected behavior. the development of the theory of neuroscience greatly influences the learning process to be more effective and meaningful.

Educational techniques that are brain friendly provide a biologically driven framework for creating effective instruction. This theory also helps explain recurring learning behaviors, and is a meta- concept that includes an eclectic mix of techniques [6].

One model encountered is the Neuroscience Model Concept for learning developed by Lila Davachi, Associate Professor of Psychology at New York University which consists of the following components:

a). Attention. Concentration focus on a task or concept without distraction. Learning something new requires focused attention. To learn new information, it must be interesting or meaningful and there must be limited distraction. Multi-tasking requires that we pay attention to more than one thing at once. Multi-tasking is best suited for habitual behaviors that require little or no cognitive input.

b). Generation. Students have direct interaction with the learning task to generate their own thoughts. Adult learning is very different from learning in childhood. Children absorb everything about their world in an uncensored way and place total trust in the adults around them. Modeling and demonstration play an important role in shaping the expected learning outcomes. The brain is a dynamic, plastic, experiential, social and affective organ

c). Emotion. Emotional cues related to learning assignments. Emotions bind memory. Like adding fuel to a flame, emotional cues trigger more neural activity in more brain centers and, as a result, burn deeper pathways. Serve learning that provides motivation so that learning becomes more meaningful. We learn better when we are in a happy and positive mood and when we are having fun. Fun learning designs will be more meaningful for children.

d). Distance. Adequate time gap to digest new learning, be consolidated, and trained. A relatively simple, but underused, way to improve learning outcomes is to reconsider how we 'empty' content. Biologically, each person's cognitive capacity will be different, the capacity is also often limited. The material presented will be more effectively presented in sequence and systematically using an attractive method.

Based on the literature study, four important points in Neuroscience-based Physical Education learning as a basic of algorithm include: 1) Multi-tasking, 2) Modelling, 3) Fun , 4) Sequences. After knowing the essential elements in neuroscience-based physical education learning, the researchers conducted a field survey consisting of the four observation indicators.

\section{Multi-tasking}

The questionnaire given to the teacher was designed to determine the application of multi-tasking in learning. This is none other than to train students' level of concentration while learning.

Table 1. Teacher Questionnaire Data on Multi-tasking in learning

\begin{tabular}{lccc}
\hline $\begin{array}{l}\text { This Is How I Think About My } \\
\text { Classroom Related To } \\
\text { Neurosaince Learing }\end{array}$ & Sample & Answer Percentage \\
\hline \multicolumn{1}{c}{ Multitasking } & n & Yes & No \\
\hline $\begin{array}{l}\text { 1. Students get motion } \\
\text { assignments with graded } \\
\text { difficulty levels }\end{array}$ & 50 & 36 & 64 \\
\hline $\begin{array}{l}\text { 2. Students perform thematic } \\
\text { motion tasks }\end{array}$ & 50 & 32 & 68 \\
\hline $\begin{array}{l}\text { 3. In our classrooms we present } \\
\text { small distractions to increase } \\
\text { student concentration }\end{array}$ & 50 & 8 & 92 \\
\hline $\begin{array}{l}\text { 4. Students get multiple motion } \\
\text { assignments (doing several tasks } \\
\text { at once, for example: jumping } \\
\text { while counting, passing } \\
\text { according to instructions) }\end{array}$ & 50 & 6 & 94 \\
\hline $\begin{array}{l}\text { 5. Students carry out movement } \\
\text { activities as instructed. }\end{array}$ & 50 & 76 & 24 \\
\hline $\begin{array}{l}\text { 6. Many students do not focus on } \\
\text { carrying out learning activities. }\end{array}$ & 50 & 70 & 30 \\
\hline $\begin{array}{l}\text { 7. Most students focus on } \\
\text { completing learning activities } \\
\text { well. }\end{array}$ & 50 & 12 & 88 \\
\hline $\begin{array}{l}\text { 8. Students have difficulty } \\
\text { carrying out multiple learning } \\
\text { activities. }\end{array}$ & 50 & 10 & 90 \\
\hline
\end{tabular}

The results of the questionnaire for the multi-tasking variable show that the teacher has actually designed the learning with multitasking activities, this is because in elementary level learning must use a thematic approach. But on the other hand, multi-tasking has not been implemented optimally, because multi-tasking instructions are still very minimal in learning (point 4). Meanwhile, most of the teachers have not trained students' concentration optimally as in point 3 . This has an impact on point 7 which shows the incompleteness of learning assignments with the available time.

\section{Fun}

Fun learning will be more meaningful for students. Fun learning can be seen from the general expression on students' faces, student participation during learning and student satisfaction after learning. 
Table 2. Teacher Questionnaire Data on Fun Aspect in learning

\begin{tabular}{|c|c|c|c|}
\hline $\begin{array}{c}\text { This Is How I Think About My } \\
\text { Classroom Related To } \\
\text { Neurosaince Learing } \\
\end{array}$ & Sample & Answe & entage \\
\hline Fun & $\mathbf{n}$ & Yes & No \\
\hline $\begin{array}{l}\text { 9. Some students want to } \\
\text { continue doing } \\
\text { activities again }\end{array}$ & 50 & 50 & 50 \\
\hline $\begin{array}{l}\text { 10. Many students compete with } \\
\text { each other to be the best }\end{array}$ & 50 & 86 & 14 \\
\hline $\begin{array}{l}\text { 11. Students feel happy when } \\
\text { learning is carried out }\end{array}$ & 50 & 86 & 14 \\
\hline $\begin{array}{l}\text { 12. Students show an indifferent } \\
\text { attitude during learning }\end{array}$ & 50 & 54 & 46 \\
\hline $\begin{array}{l}\text { 13. Some students don't want to } \\
\text { study }\end{array}$ & 50 & 14 & 86 \\
\hline $\begin{array}{l}\text { 14. Some students do not like } \\
\text { class }\end{array}$ & 50 & 32 & 68 \\
\hline $\begin{array}{l}\text { 15. All students feel that they are } \\
\text { close friends with each other }\end{array}$ & 50 & 82 & 18 \\
\hline 16. Our classes are so much fun & 50 & 84 & 16 \\
\hline $\begin{array}{l}\text { 17. Students mostly enthusiastic } \\
\text { about performance, want to be } \\
\text { the first to appear. }\end{array}$ & 50 & 54 & 46 \\
\hline
\end{tabular}

The interesting thing from this finding is that students feel very happy in learning physical education. However, the enthusiasm of students in carrying out physical education learning activities is still at the middle level. This means that there are still many students who do not want to repeat learning again. They may carry out learning activities only during school hours, but have not yet internalized it into a habit outside of school / class. It is necessary to trace the level of student enjoyment in an activity so that it becomes a habit he does without being ordered.

\section{Modelling}

Modeling is an important element in physical education learning, especially in Indonesia. this is closely related to communication and actualization. In Indonesia, a teacher has a duty as a role model for students. especially at the basic level. Students in primary schools have excellent imitation abilities. So that whatever he sees, does and learns can shape it at a later date.

Table 3. Teacher Questionnaire Data on modelling in learning

\begin{tabular}{lcccc}
\hline $\begin{array}{c}\text { This Is How I Think About My } \\
\text { Classroom Related To } \\
\text { Neurosaince Learing }\end{array}$ & Sample & \multicolumn{2}{c}{$\begin{array}{c}\text { Answer } \\
\text { Percentage }\end{array}$} \\
\hline \multicolumn{1}{c}{ Modelling } & n & Yes & No \\
\hline $\begin{array}{l}\text { 18. The teacher provides a good } \\
\text { example }\end{array}$ & 50 & 82 & 18 \\
\hline $\begin{array}{l}\text { 19. Students idolize teachers } \\
\begin{array}{l}\text { 20. There are students who are } \\
\text { respected in the class }\end{array}\end{array}$ & 50 & 84 & 16 \\
\hline $\begin{array}{l}\text { 21. Teachers provide examples of } \\
\text { positive behavior to students }\end{array}$ & 50 & 100 & 10 \\
\hline
\end{tabular}

The modeling concept has been applied very well by teachers and even presents in the class itself. This may be a very potential strength for teachers in DKI Jakarta to create meaningful learning.

\section{Sequences}

The ordering and mapping of material in the curriculum is common and is an obligation for every educator.

Table 4. Teacher Questionnaire Data on Curriculum Sequences in learning

\begin{tabular}{|c|c|c|c|}
\hline \multirow{2}{*}{ 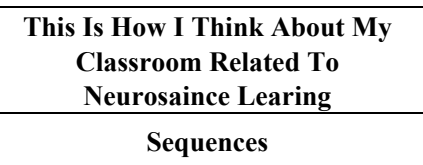 } & \multirow{2}{*}{$\begin{array}{c}\text { Sample } \\
\mathbf{n}\end{array}$} & \multicolumn{2}{|c|}{$\begin{array}{l}\text { Answer } \\
\text { Percentage }\end{array}$} \\
\hline & & Yes & No \\
\hline $\begin{array}{l}\text { 22. The material is presented } \\
\text { sequentially }\end{array}$ & 50 & 10 & 90 \\
\hline $\begin{array}{l}\text { 23. The material starts from easy to } \\
\text { difficult }\end{array}$ & 50 & 36 & 64 \\
\hline 24. Learning is carried out in stages & 50 & 100 & 0 \\
\hline $\begin{array}{l}\text { 25. The teacher analyzes the } \\
\text { learning before compiling the } \\
\text { curriculum }\end{array}$ & 50 & 80 & 20 \\
\hline
\end{tabular}

By recognizing existing material, teachers can map the material more precisely. The continuous and gradual placement of the material will reduce the stress level of students while studying, thus learning becomes more effective. The positive side of the findings in this variable is that the teacher has conducted material analysis and the curriculum to be taught, but on the other hand, the teacher has not carried out the material arrangement continuously. This is an important note for neuroscience-based learning, that teachers not only analyze the curriculum but also have to organize the distribution of the material on an ongoing basis so that the material conveyed to children becomes more optimally accepted by children.

\section{Conclusions}

A search of related theories, shows that the concept of neuroscience can be compatible with physical education learning. Some evidence shows that physical education has a contribution to brain and cognitive development, besides that physical education has the potential to be a supporter in optimizing the overall aspects of a child. In fact, developments are now starting to include physical activity in between lessons to optimize brain performance and give the brain a break for relaxation.

Neuroscience-based physical education learning is something new in Indonesia. Not many teachers have applied this learning, although learning will not be separated from the role of neuroscience. Neuroscience-based learning is very possible in physical education learning, this will be very beneficial for students because both sides of both physical activity and cognitive development will influence each other. 
Neuroscience-based learning has essential elements, including concentration (through multitasking), modeling, fun, and sequences. Neuroscience-based learning can be seen in the presence of these four variables.

Concentration indicators in learning through multiple assignment instructions have not yet appeared in the learning being carried out. Intrusion with multi-tasking patterns will increase student concentration, so that students really have an essential learning experience.

In terms of pleasure in learning, the teacher has created a pleasant atmosphere and almost half of the sample of teachers stated that the learning environment was pleasant. An important finding in this conception is that the level of student enjoyment must be reached at what level to make the learning experience a daily habit, because students who feel happy tend not to repeat related activities outside the classroom.

The modeling done by DKI Jararta physical education teachers has been very good. Even physical education teachers have become idols of many students. This is the strength of the teachers in the success of their learning in the future.

The curriculum analysis has been carried out by the teachers along with the curriculum documents. However, the continuous arrangement of the material has not been implemented optimally. The material needs to be reviewed and organized according to its relevance. Because new abilities will be more optimal when it comes to previous abilities.

Based on the existing model, the researcher offers a basic neuroscience based physical education learning model algorithm including 1) multi-tasking, 2) modeling, 3) fun, 4) 00sequences. This algorithm certainly needs to be investigated further through a series of subsequent research and development.

\section{Acknowledgments}

Researchers would like to thank their research team colleagues and other support staff who were involved in this research. In addition, the researchers would like to thank the Jakarta State University for financing this research activity from beginning to end. Not to forget that the researchers expressed their highest appreciation and gratitude to the schools in DKI Jakarta with the extraordinary teachers and students who were very enthusiastic in supporting this research.

\section{REFERENCES}

[1] R. Nummela, Teaching and the Human Brain, vol. 3, no. 2. 2014.

[2] C. Hinton, K. W. Fischer, and C. Glennon, "Mind, Brain, and Education Editors' Introduction To the Students At the Center Series," Mind, Brain Educ. students Cent. Ser., pp. 128, 2012.

[3] S. Rushton, A. Juola-Rushton, and E. Larkin, "Neuroscience, play and early childhood education: Connections, implications and assessment," Early Child. Educ. J., vol. 37, no. 5, pp. 351-361, 2010.

[4] S. Vorhauser-Smith, "The Neuroscience of Learning \& Development," pp. 1-18, 2011.

[5] B. D. McCandliss, "Educational neuroscience: The early years," Proc. Natl. Acad. Sci. U. S. A., vol. 107, no. 18, pp. 8049-8050, 2010.

[6] J. Ramakrishnan, "Brain Based Learning Strategies," Int. J. Innov. Res. Stud., no. April, 2018.

[7] E. E. Alava and M. E. M. Martinez, "Impact of teaching-learning process for brain," Int. J. Health Sci. (Qassim)., vol. 3, no. 1, pp. 33-40, 2019.

[8] B. M. Gearin and H. Fien, "Translating the neuroscience of physical activity to education," Trends Neurosci. Educ., vol. 5, no. 1, pp. 12-19, 2016.

[9] J. E. Donnelly et al., "Physical activity, fitness, cognitive function, and academic achievement in children: A systematic review," Med. Sci. Sports Exerc., vol. 48, no. 6, pp. 1223-1224, 2016.

[10] B. M. Gearin and H. Fien, "Translating the neuroscience of physical activity to education," Trends Neurosci. Educ., vol. 5, no. 1, pp. 12-19, 2016.

[11] S. Kubesch et al., "A 30-Minute physical education program improves students' executive attention," Mind, Brain, Educ., vol. 3, no. 4, pp. 235-242, 2009.

[12] A. Reid, "Folk Psychology, Neuroscience and Explanation in Physical Education," Eur. Phys. Educ. Rev. Rev., vol. 5, no. 199906, pp. 101-120, 2015.

[13] L. N. Chukwurah, O. I. Abbah, C. N. Iweama, J. E. Ogugua, and J. Ameh, "Students' achievement in physical and health education: Effect of discussion teaching method," International Journal of Human Movement and Sports Sciences, vol. 8, no. 3, pp. 86-90, 2020.

[14] B. A. Sibley, "The Relationship between Physical Activity and Cognition in Children : A Meta-Analysis and Cognition in Children : A Meta-Analysis," no. August 2015, 2003.

[15] M. S. Hajar, H. Rizal, Y. C. Kueh, and A. S. Muhamad, "The E ff ects of Brain Breaks on Motives of Participation in Physical Activity among Primary School Children in Malaysia,” 2019.

[16] A. Glapa et al., "The Impact of Brain Breaks Classroom-Based Physical Activities on Attitudes toward Physical Activity in Polish School Children in Third to Fifth Grade.”

[17] M. De Souza Martins, S. Posada-Bernal, and P. A. Lucio-Tavera, "Physical education in the early childhood: A perspective of investigation in education from the neuroscience," IMSCI 2017 - 11th Int. Multi-Conference Soc. Cybern. Informatics, Proc., vol. 15, no. 4, pp. 181-184, 2017. 